\title{
A GIS-AHP-based approach in siting MSW landfills in Lokoja, Nigeria
}

\author{
James R. Adewumi ${ }^{1}$. Ocheje J. Ejeh ${ }^{1} \cdot$ Kayode H. Lasisi ${ }^{1}$ · Fidelis O. Ajibade ${ }^{1,2}$
}

Received: 29 June 2019 / Accepted: 14 October 2019 / Published online: 1 November 2019

(c) Springer Nature Switzerland AG 2019

\begin{abstract}
The acute shortage and scarcity of lands for suitable waste disposal is rapidly becoming a critical growing potential problem in most urban cities in developing countries of the world, and several fast-growing cities in Nigeria are not exempted from this menace. In this study, geographic information system (GIS) and analytic hierarchy process (AHP) are combined to select the most suitable landfill location in Lokoja, Nigeria. The landfill site selection criteria considered include proximity to major road, powerline, water body, landfill areas and built-up area. GIS was used to digitize spatial features related to unsuitable landfill site. A total of 19 candidate landfill sites were identified from GIS analysis. AHP model was developed from the GIS result as multi-criteria decision tool in evaluating each candidate site so as to choose the best appropriate landfill site. AHP model rated candidate site 11 located along Jimgbe road has the most preferable site to locate a landfill in Lokoja with an approximate area of $3.4204 \mathrm{~km}^{2}$; the distance from the minor road, nearest water body, powerline and built-up areas to the location is $210.50 \mathrm{~m}, 1408.20 \mathrm{~m}, 1810.80 \mathrm{~m}$ and $205.61 \mathrm{~m}$, respectively. Also, the model rated candidate site 16 located along 500 housing units as the least preferable site to locate a landfill in Lokoja. The characteristic features of the site location as obtained from GIS analysis include an approximate area of $2.5680 \mathrm{~km}^{2}$ at an approximate distance of $2430.75 \mathrm{~m}, 594.04 \mathrm{~m}, 1980 \mathrm{~m}$ and $200.68 \mathrm{~m}$ from the major road, water body, powerline and built-up areas, respectively. This result will greatly serve as guide in landfill site selection in major urban states of other developing countries.
\end{abstract}

Keywords GIS · AHP · Site selection · Multi-criteria decision (MCD) · Landfill

\section{Introduction}

A pertinent issue which is related to environmental management via proper supervision and control of solid waste, pollution and health risks which arise in open dumping sites that are often commonly used for waste disposal is termed solid waste management (SWM) [1-4]. The menace of environmental pollution ensuing from indiscriminate waste disposal through open and poor waste disposal techniques has been a threat to the inhabitants of most developing countries [5-7], and its harmful effects on the (soil and water) environment and human health are considered to be frightening [8-11]. Throughout history, the commonest technique of organized waste disposal has been landfills and it has remained so in several places worldwide. Some landfills have been utilized in waste management application such as temporary storage and the combining, transferring and processing of waste material [12]. Landfills have also proved to be productive relative to the cost of waste disposal, particularly in locations having large spaces that are opened. As incineration, resource recovery and materials recovery require large

Electronic supplementary material The online version of this article (https://doi.org/10.1007/s42452-019-1500-6) contains supplementary material, which is available to authorized users.

Fidelis O. Ajibade, foajibade@futa.edu.ng| 'Department of Civil and Environmental Engineering, Federal University of Technology, Akure, Nigeria. ${ }^{2}$ University of Chinese Academy of Sciences, Beijing 100049, China. 
investments in infrastructure, and extensive manpower to maintain, landfills have low capital and operational costs which make them compete favourably. In addition to the aforementioned benefits of landfill, gas generated from it can be improved to natural gas for domestic utilization which is a potential revenue stream [13].

Most cities and communities all over the world are often faced with task of making a suitable decision when finding the most appropriate sites for new landfills $[14,15]$ as process of making choice is a complex procedure since social, environmental and technical factors must be considered together $[16,17]$. Siting evaluations are ruled by employing the pre-existent land-use changes in the developed area as well as the nature of plausible interactions of the landfill with the previous environmental, geologic, hydrological and socioeconomic parameters of the area [18]. Siddiqui et al. [19] had been amongst the first to combine GIS and AHP for landfill siting. This integration performs an extensive function in locating landfills for waste management. Some techniques have been singularly used in landfill site selection study such as geographic information systems (GISs) [20,21], analytical hierarchy process (AHP), analytical network process (ANP), simple additive method (SAM), weighted linear combination (WLC), multicriteria decision analysis (MCDA) and fuzzy logic [22-24], whereas in some studies, two or more techniques were combined. In recent studies, Chabuk et al. [25] combined GIS and MCDA methods for selecting landfill of an area in Iraq called Al-Hashimiyah Qadhaa in Babylon. Two landfill locations which were suitable candidates were identified in Al-Hashimiyah Qadhaa which were able to retain solid waste from years 2020 to 2030. Moeinaddini et al. [26] and Salman and Gholamalifard [27] experimented on landfill siting through weighted overlay using the weighted linear combination (WLC) method. Bottero et al. [28] combined AHP and ANP methods in selecting in a landfill site. Pandey et al. [29] employed in Bhagalpur, India, an expert-based ranking method for selecting suitable municipal solid waste (MSW) landfill site. Isalou et al. [30] systematically distributed fuzzy logic by integration into ANP in another part of Iran. All the aforementioned researcher's findings revealed that combining two or more methods can help define and select a site that is more appropriate than applying them differently.

In the consideration involving all factors in landfill siting techniques, the combination of GIS and AHP will form an efficient tool to solve the problem of landfill site selection and also to research criteria within the modelling process. It is generally used to consider location problems [31]. GISs provide competent manipulation and presentation of data and can manage great bulk of spatially distributed data from a variety of sources as it effectively stores, recover, examine and show information in accordance with the user-defined specifications [26, 32], while AHP helps to rank suitable sites and choose the best one as it supplies consistent ranking of the potential landfill areas based on a variety of criteria available [33]. This study is aimed at combining GIS with AHP techniques coupled with field analysis for analysing the best location for landfill siting in Lokoja, Nigeria.

\section{Materials and methods}

\subsection{Study area}

Lokoja is the capital of Kogi State with a total population of about 196,643 in 2006 [34] with approximate area of $3180 \mathrm{~km}^{2}$ with location between latitude $7^{\circ} 46^{\prime} \mathrm{N}-7^{\circ} 52^{\prime} \mathrm{N}$ and longitude $6^{\circ} 38^{\prime} \mathrm{E}-6^{\circ} 46^{\prime} \mathrm{E}$. The city is the seat of government activities in the state, a factor majorly responsible for its urbanization. The major occupations of the indigenes are farming, fishing and weaving. It is also a trade centre with respect to its agricultural products because of its proximity to the new Federal Capital of Nigeria in Abuja. Lokoja is also, the headquarter of Lokoja Local Government, and the major confluence town in Nigeria. The study area enjoys both wet season from March to November and dry seasons from December to February with a total annual rainfall ranging between 804.5 and $1767.1 \mathrm{~mm}$. The mean annual temperature is about $27.7^{\circ} \mathrm{C}$ having $30 \%$ and $70 \%$ relative humidity in both dry and wet seasons. Mean daily wind speed and vapour pressure are $89.9 \mathrm{~km} / \mathrm{h}$ and $26 \mathrm{Hpa}$, respectively. One paramount hydro-geological feature in the study area is the River Niger and the confluence of Rivers Niger and Benue [35]. The geology of the study area consists of mainly of Precambrian basement complex rock and elevation on the western side which varies from 273 to $333 \mathrm{~m}$ above sea level while on the eastern side it varies from 273 to $364 \mathrm{~m}$. Figure 1 represents administrative map of Kogi State showing some settlements and the study area (Lokoja).

\subsection{Data acquired and source}

This study combines spatial data analysis in GIS environment with multi-criteria decision-making process. Map of the area was firstly georeferenced and subsequently digitized to show criteria features considered for selecting landfill site of municipal solid waste in the GIS environment. Buffer analysis was performed on the digitized features to exclude areas where municipal solid waste landfill cannot be located. Maps showing criteria features and buffer analysis were subsequently prepared. The buffered maps were analysed to show potential landfill sites in the 
Fig. 1 Map showing study area in Kogi State, Nigeria

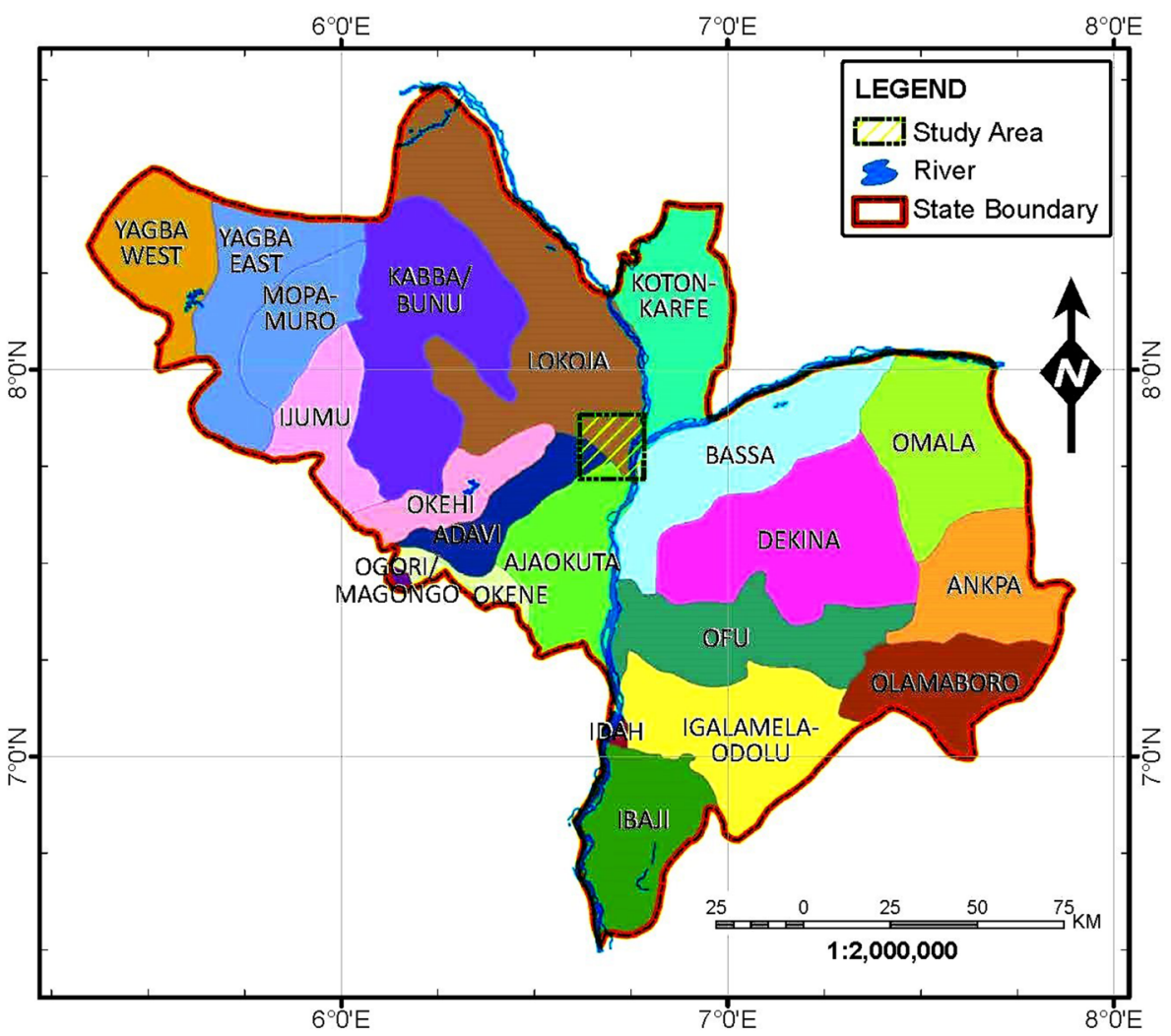

study area. Based on geographical location and characteristic features, the potential landfill sites were reduced and the AHP model was adopted as a MCDA making process to identify the best landfill site in the study area.

\subsection{Data gathering}

The data needed for this research include available analogue maps, digital elevation modem (DEM) and digitalized maps showing required features. The digital maps contain information on built-up areas, housing estates, property boundaries, undeveloped areas, water bodies, air-strip, pipeline, road network and railway line within the study area. Then, the available analogue maps containing the features required for the study area are scanned and saved.

\subsection{Digitization}

For the process of digitization, new layers are created in the ArcCatalog by creating a personal geodatabase. From the personal geodatabase (this personal geodatabase is renamed to reveal different features from the scanned maps), new features for road, water bodies and land use were then created for various features on the scanned map.

\subsection{Buffering}

The buffering operation was performed from the ArcMap window by choosing "Buffer" from the analyst tools in the ArcTool Box. The linear distances for creating buffer zones around the various features were adapted from Sumathi et al. [20] having linear distances of $200 \mathrm{~m}$ each for road and river buffer, respectively. A linear distance of $500 \mathrm{~m}$ was adopted for land-use/land-cover buffer [18] and $1500 \mathrm{~m}$ linear distance for power station buffer [15].

\subsection{Extraction of potential landfill sites}

The potential landfill sites were extracted from the combined buffer maps by removing the combined buffer areas obtained via map overlay.

\subsection{Application of AHP in siting solid waste landfill}

For valuation of the criteria features obtained from the GIS analysis, various methods such as logistic regression, AHP, weight of evidence, ratio estimation and the Delphi process could be chosen. AHP model was adopted in this research in order to give value to the criteria and select the best appropriate site. The incorporation of AHP and GIS facilitates decision-making process significantly [36, 37]. Satty [38] was the first to propound AHP and it is asserted 
Fig. 2 Hierarchy in AHP for selection of landfill site

Table 1 Comparison scale in AHP. Source: Saaty (1980)

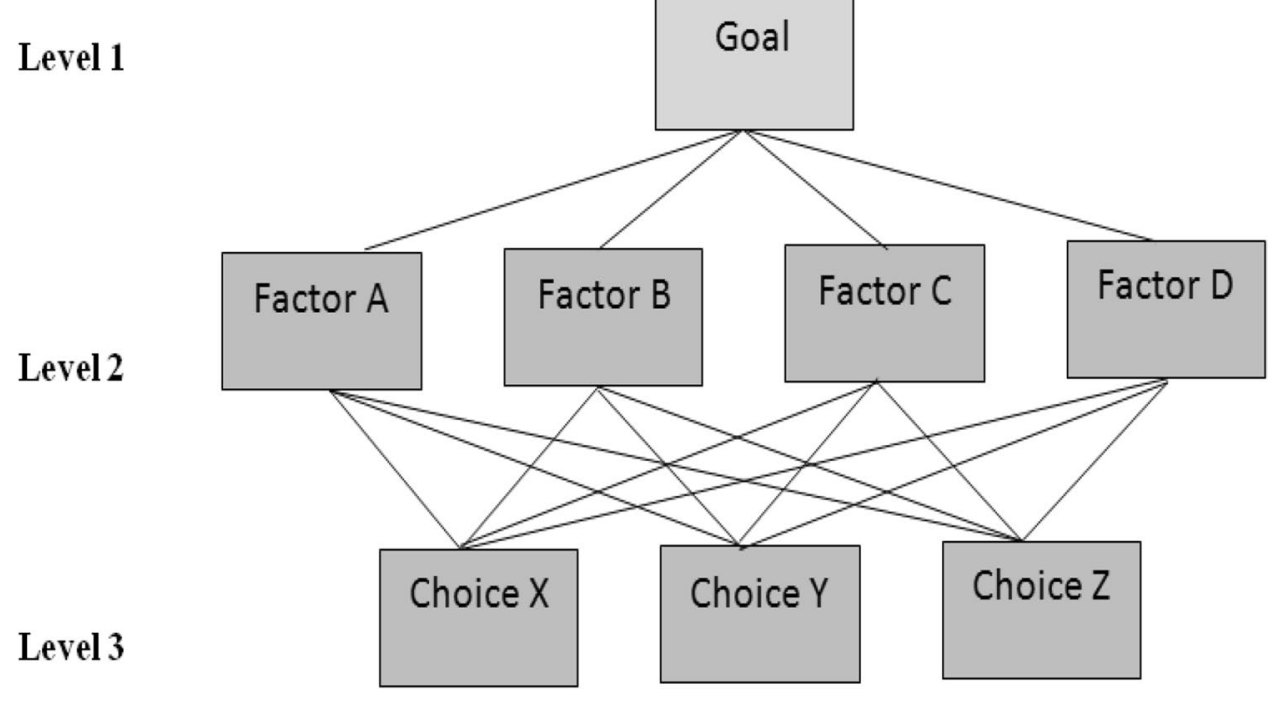

\begin{tabular}{ll}
\hline Level of relevance & \\
\hline 9 & Absolute relevance \\
7 & Demonstrated relevance \\
5 & Essential or strong relevance \\
3 & Weak relevance of one over another \\
1 & Equal relevance \\
$2,4,6,8$ & Intermediate values between the two adjacent judgments \\
Reciprocal of the above nonzero & $\begin{array}{l}\text { If activity } i \text { has one of the above nonzero numbers assigned to it } \\
\text { when compared with activity } j \text {, then } j \text { has the reciprocal value } \\
\text { when compared with } i\end{array}$ \\
\hline
\end{tabular}

to be one of the best decision-making methods. It is one of the most all encompassing systems designed for making multi-criteria decisions since it relates the prospect for developing problems in a hierarchical manner [39]. It is a flexible and powerful tool for both qualitative and quantitative investigation of multi-criteria problems [40]. AHP is characterized based on paired comparisons as it is helpful in breaking down complicated problems with multiple criteria into number of matched comparisons [41].

\subsection{AHP process in selecting the best landfill site}

The development of AHP model using criteria features obtained from the GIS analysis help to rank alternatives (candidate landfill sites) in order of priorities. Figure 2 depicts the AHP process that was used for the selection of the best landfill site. The topmost level (level 1) of the hierarchical structure represents the main goal which is the location of the best suitable site. Level 2 represents the criteria considered in the selection process which involves the characteristics features of candidate sites obtained from the GIS analysis. The last level (level 3) represents various alternatives (candidate landfill sites) represented in GIS analysis. However, the alternatives are trimmed down to reasonable numbers owing to the geographical location of the site or land area considered.

The AHP method mainly allows assigning a priority to a number of decision alternatives and/or to relate criteria characterized by qualitative and quantitative assessments (often not directly comparable), combining multidimensional measures into a single scale of priorities [38]. AHP is used to derive ratio scales from paired comparisons [19, 21, 42-44]. Using a nine-point scale which includes 9, 8, $7, \ldots, 1 / 7,1 / 8,1 / 9$, the comparison was made, where 9 represents extreme preference, 7 represents very strong preference, 5 represents strong preference, and so on until it gets down to 1 , which signify no preference (Table 1). This pair-wise comparison permits for an independent rating of each factor's contribution, which therefore simplify the decision-making process. The pair-wise comparisons of different criteria were usually arranged into a square matrix with the diagonal elements of the matrix being 1 . Bhusan and Rai [45] observed that the corresponding normalized right eigenvector and the principal eigenvalue of 
the comparison matrix gave the relative importance of the criteria being compared. The elements of the normalized eigenvector were weighted with respect to the criteria or sub-criteria and rated with respect to the alternatives.

The consistency check offered by AHP makes it a unique tool in the cause of decision-making [46]. The consistency check allows for improvement in making decision. The consistency of judgment can be determined by the eigenvalue method which evaluates maximum eigenvalue $\left(\lambda_{\max }\right)$ of the pair-wise comparison matrix [47]. The comparison matrix for a given $n$ rows and $n$ columns is given by the matrix relation.

$A=a_{i j}=a_{21}\left(\begin{array}{llll}a_{11} & a_{12} & \ldots & a_{1 n} \\ a_{22} & \ldots & a_{2 n} & \\ a_{n 1} & a_{n 2} & \ldots & a_{n n}\end{array}\right)$

where $a_{i j}$ is the value obtained from the fundamental scale of comparison.

The maximum eigenvalue $\left(\lambda_{\max }\right)$ is evaluated from the average column vector determined from the following relation.

$\left(\begin{array}{c}\lambda_{1} \\ \lambda_{2} \\ \vdots \\ \lambda_{n}\end{array}\right)=\left(\begin{array}{llll}a_{11} & a_{12} & \ldots & a_{1 n} \\ a_{21} & a_{22} & \ldots & a_{2 n} \\ \vdots & \vdots & & \\ a_{n 1} & a_{n 2} & \ldots & a_{n m}\end{array}\right)$

where $\lambda_{n}$ is the eigenvalue.

$\mathrm{PV}_{n}$ is the priority vector.

The priority vector for the comparison matrix formed is evaluated from Eq. 2, while the maximum eigenvalue is computed using Eq. 3.

$\mathrm{PV}=\frac{\frac{a n_{1}}{\sum a i_{1}}+\frac{a n_{2}}{\sum a i_{2}}+\cdots \frac{a n_{n}}{\sum a i_{n}}}{n}$

$\lambda_{\max }=\frac{\lambda_{1}+\lambda_{2}+\cdots+\lambda_{n}}{n}$

The consistency ratio (C.R) which evaluates the consistency in judgment is given by the relation.

Consistency Ratio (C.R) $=\frac{\text { C.I }}{\text { R.I }}$
The judgment is considered to be consistent if the consistency ratio (C.R) is less than 0.1 ; else the judgment has to be re-evaluated to ensure proper decision-making. It must, however, be noted that the priorities vector must always add up to unity with C.I representing consistency index and R.I representing random consistency index. The random consistency index (R.I) is the average of C.I shown in Eq. 5.

C.I $=\frac{\lambda_{\max }-n}{n-1}$

where $\lambda_{\max }$ represents the maximum eigenvalue and $\mathrm{n}$ represents the number of rows or columns in the comparison matrix. Therefore, C.I can further be calculated as:

C.I $=1.98\left[\frac{n-1}{\frac{n}{2}(n-1)}\right]$

1.98 is the average value of the ratio of each value computed for $n=3-15$

\section{Results and discussion}

\subsection{Generated maps from spatial features}

The map of the road network, water body, powerline and land use/land cover of the research area is illustrated in Figs. 3, 4, 5 and 6, respectively. The road map features both major roads and minor roads with the major roads consisting of dual- and single-carriage roads with large volume of traffic along Natako-Abuja express way, Lokoja ultra-modern market road and Ganaja-Otokiti Estate road while the minor roads shows small volume of traffic compared to the major roads. Water body map consists of major rivers and streams. The major rivers are River Niger and River Benue, while the minor ones include Meme River and River Zango. The powerline station map shows grid lines direction from the state capital to other neighbouring town and communities. The landuse/landcover map shows the built-up areas (residential areas, commercial areas and developed housing estates), undeveloped areas and other extensions where appropriate landfill can be correctly sited. 


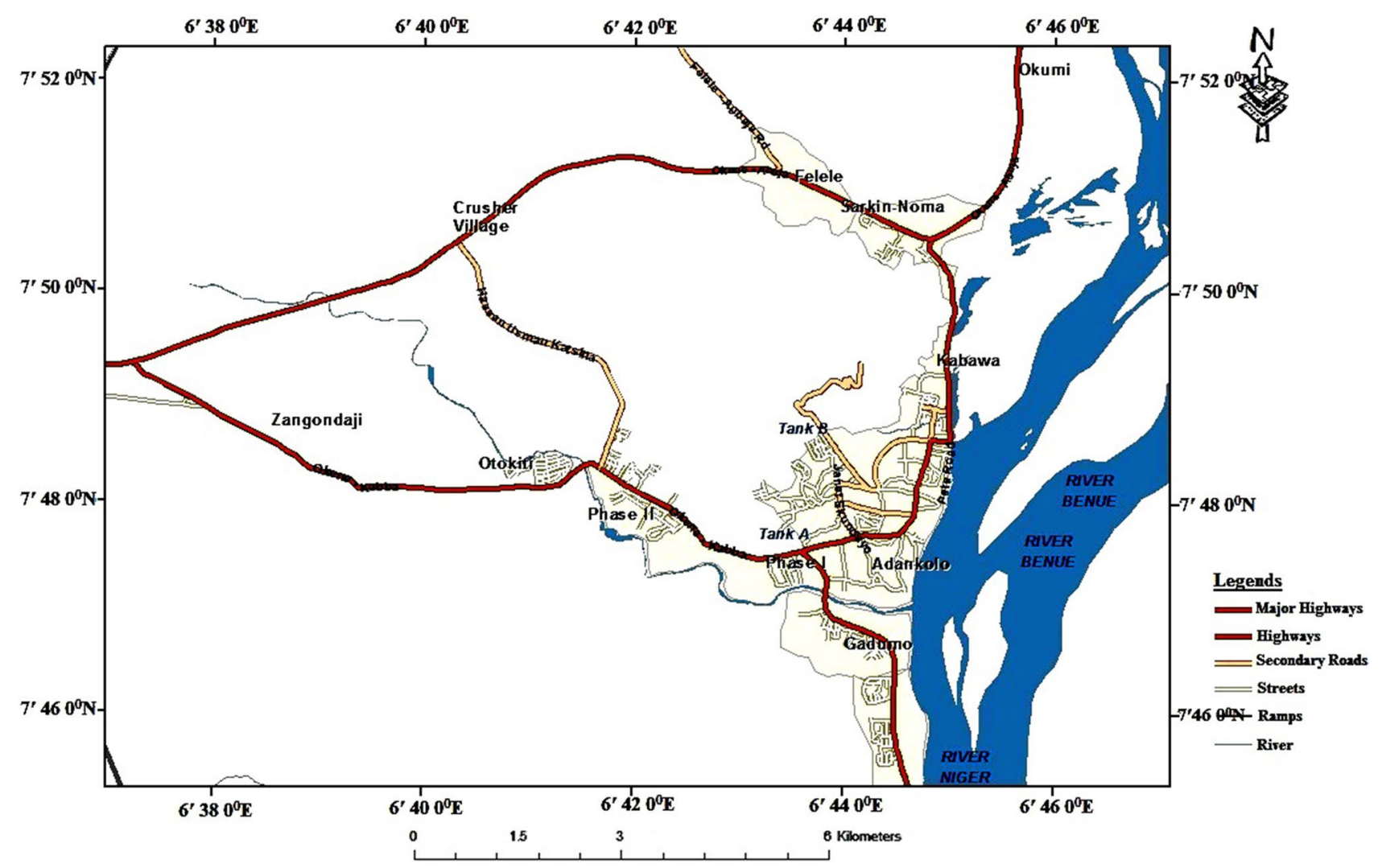

Fig. 3 Road network map in the study area

\subsection{Buffer analysis of digitized features}

Maps prepared from the buffer analysis show suitable areas and unsuitable areas required for sanitary landfill in the area.

\subsubsection{Distance to Road}

The road buffer map in Fig. 7 shows areas where municipal solid waste landfill site cannot be sited while the unlabelled areas are areas suitable for municipal solid waste landfill location based on the EPA standards for municipal waste landfills location. Areas less than $100 \mathrm{~m}$ from the road (especially major roads) are unsuitable for landfill, distances from road greater than $2000 \mathrm{~m}$ are less suitable, while a distance between 100 and $1000 \mathrm{~m}$ is mostly considered suitable. This result is in agreement with the studies of Allen et al. [48] and Khan and Samadder [49] who affirmed that a distance greater than $1 \mathrm{~km}$ from main roads and highways should be strongly avoided while supporting their assertions that, landfill sites placed too far away from existing road networks most often incur expensive cost of constructing new roads and also increase the transportation and collection costs of solid wastes. A distance between 200 and $500 \mathrm{~m}$ from the main road is considered most suitable which is in tandem with the assertions made by Al-Anbari et al. [50] and Karimi et al. [51]. The potential landfill located in this suitable location ensures solid wastes are transported to site at reasonable cost.

\subsubsection{Distance to water bodies}

The water bodies buffer map in Fig. 8 reveals the uncoloured zones suitable for landfill location while the "blue" zone is not proper for siting landfill. The uncoloured zones are areas $>100 \mathrm{~m}$ from water bodies which 


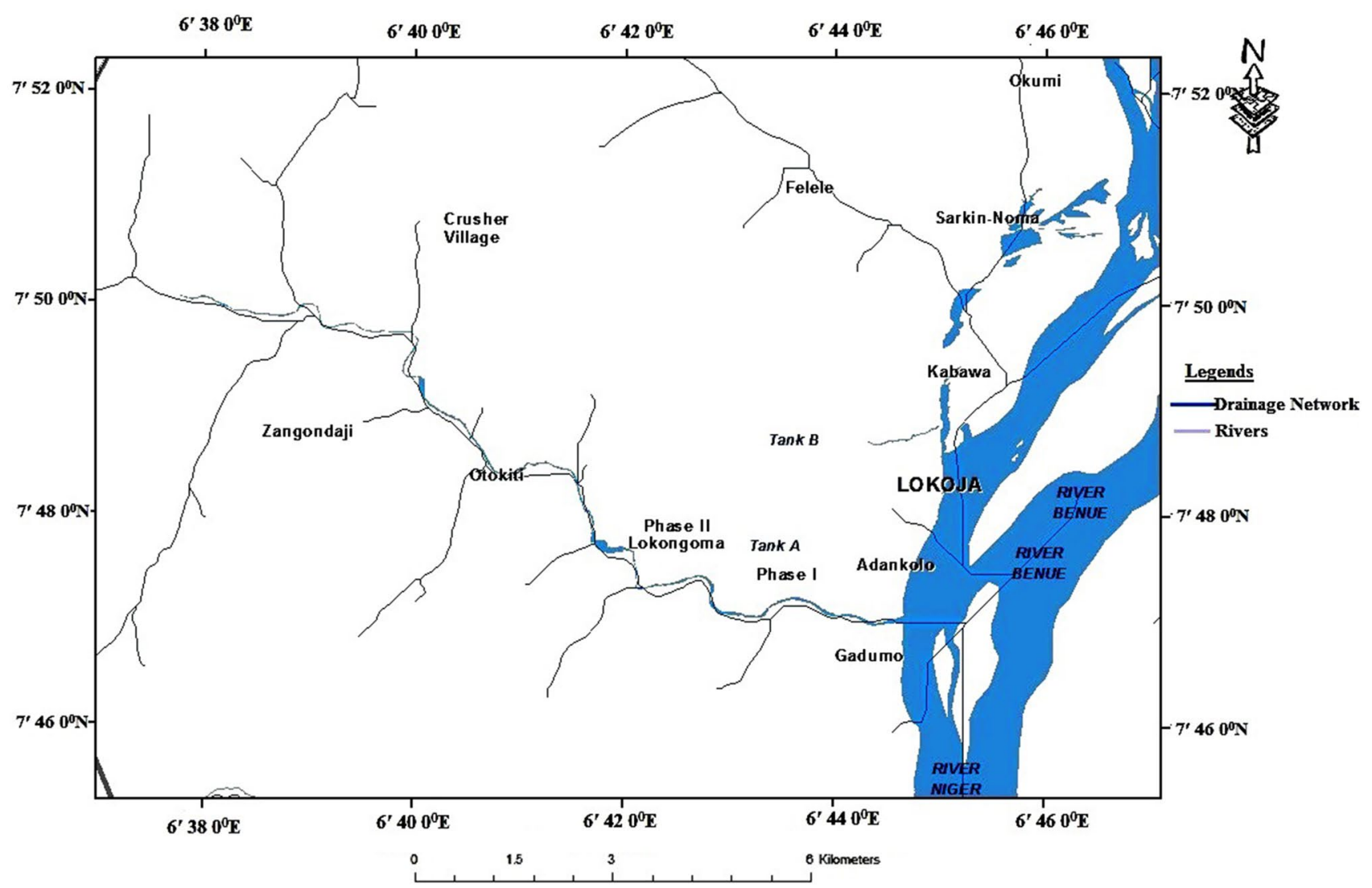

Fig. 4 Water body map in the study area

are considered suitable for siting landfill while the blue zone are areas $<100 \mathrm{~m}$ from water bodies considered as unsuitable. Distance from water bodies (especially for surface water bodies) was buffered at varying distance not $<500 \mathrm{~m}$. For groundwater bodies, areas having the maximum depth of water table from ground surface were buffered. Only distance from the water bodies more than $500 \mathrm{~m}$ was considered safe for constructing landfill in the study area. This is to ensure water bodies in the study area are not polluted. Dorhofer and Siebert [52] agree to the fact that as landfills release pernicious gases and leachate, they should not be in proximity to water wells and surface water bodies. For groundwater bodies, landfill site should be located in area where they are sufficiently deep in order not to affect leachate movement. Similarly, this result is in agreement with the findings and assertions of Manual on Municipal Solid Waste Management [53], Khan and Samadder [49] and Yousefi et al. [54] on siting MSW landfill.

\subsubsection{Distance to powerline}

The powerline buffer map displayed in Fig. 9 portrays the uncoloured zones appropriate for landfill location, whereas the "blue, red, yellow and light red" zones are not inappropriate for siting landfill. These uncoloured zones are areas with distance more than $30 \mathrm{~m}$ away from the high-voltage powerlines. This result is in line with Al-Ansari et al. [55] who asserted that landfill site locations should not disturb infrastructures including high-voltage powerlines. It is also in tandem with the findings of Al-Anbari 




Fig. 5 Map showing powerline in the study area

et al. [56] who classified layer of powerlines by assigning values in Al-Hashimiyah Qadhaa as suitable (for powerlines having distance $>30 \mathrm{~m}$ ) and unsuitable (for powerlines having distance from 0 to $30 \mathrm{~m}$ ).

\subsubsection{Land use/land cover}

Land use is vital to resolving public scuffle of the endorsement of unnecessary area of landfill amenities $[57,58]$. The land-use buffer map was prepared so as to avoid odour resulting from landfill sited within the study area. The "red" zones are areas where municipal solid waste landfill cannot be situated, while the blue zones are locations where municipal solid waste landfill can be stationed. The red zones include residential and other settlement areas, recreational areas, vegetation and airport areas. These areas were assigned relatively high grade in order to discard them for landfilling while the blue zones include areas which are exclusively barren lands without and with some scrubs. They were considered as suitable for siting landfills and hence were thus assigned low grades. These land-use/ land-cover factors considered are similar to the findings of Khan and Samadder [49] and Kapilan and Elangovan [59]. Settlements were also given due consideration, as landfill site should not be in the vicinity of residential or urban area to avoid adverse impact on land value and future development. This will protect the people from possible environmental hazards resulting from landfill sites. According to Demesouka et al. [60], landfill must be located within $10 \mathrm{~km}$ but should not be within $500 \mathrm{~m}$ of an urban area. A distance of more than or equal to $250-500 \mathrm{~m}$ from settlement was taken as suitable for landfill siting in this study. The airport and pipeline buffer maps are provided in supplementary file (Figs. S1 and S2). 


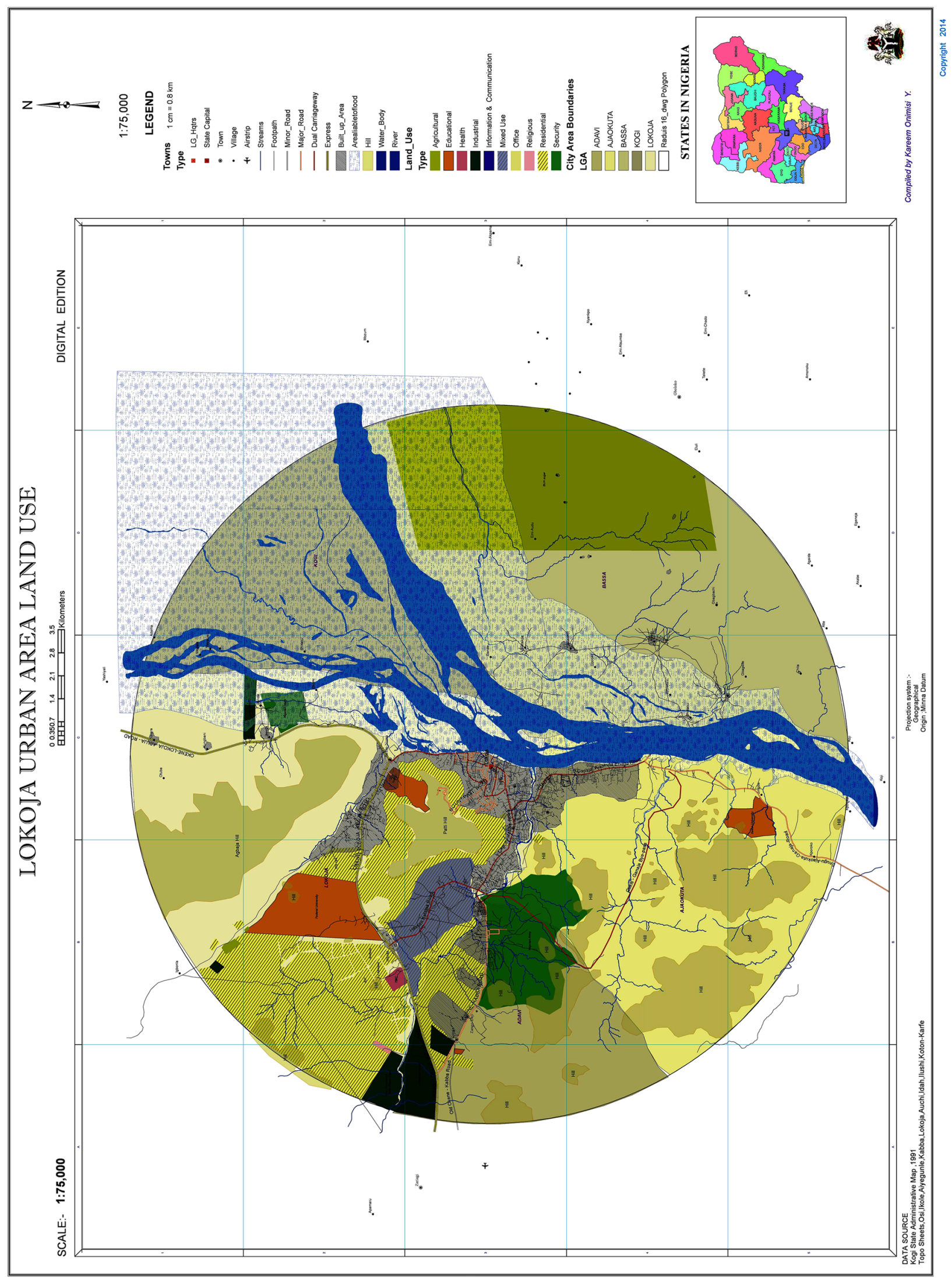

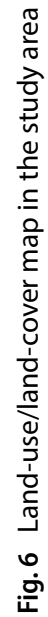




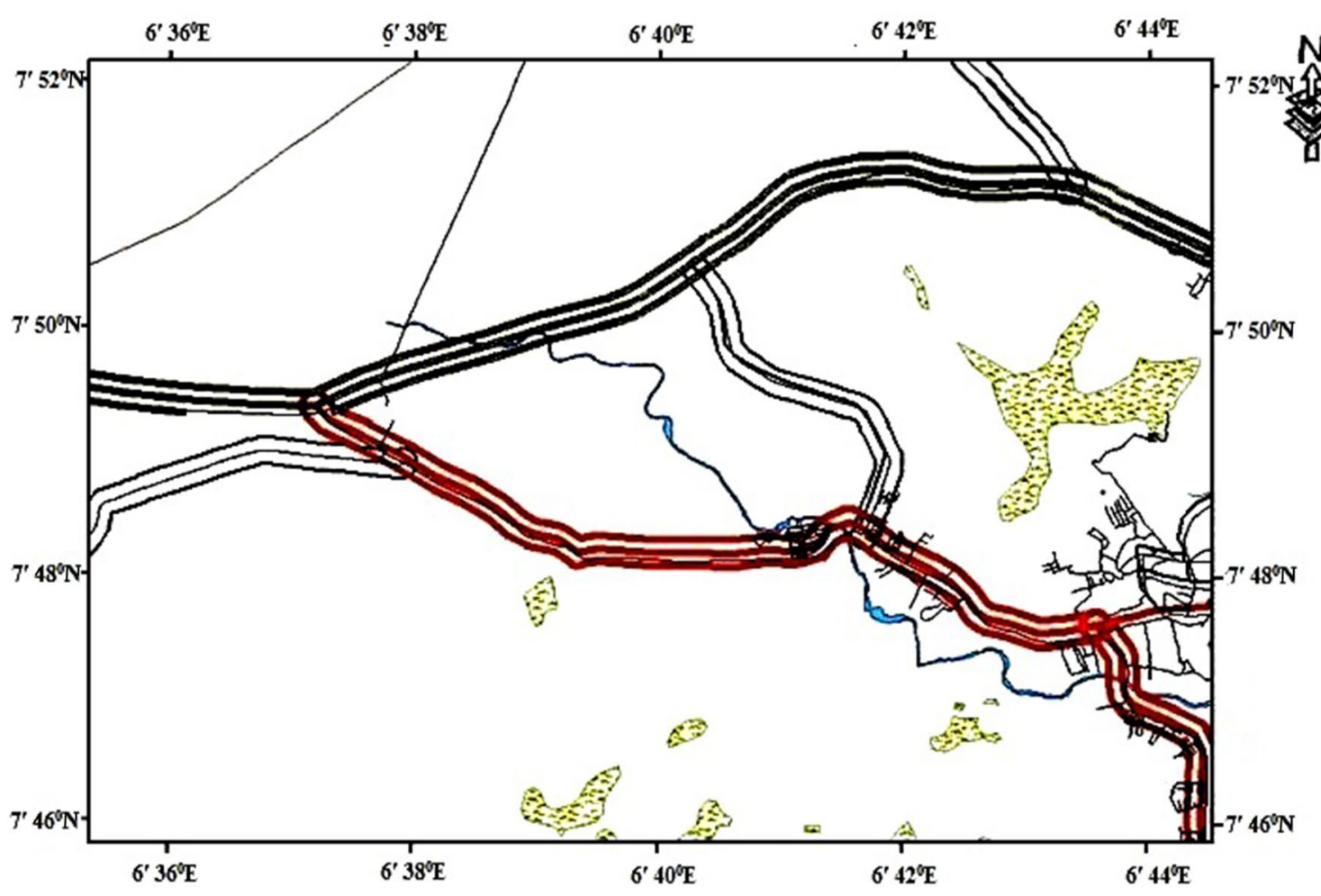

Legends

- Streets

- Expressway

- Highway

- Main Roads

- Pipelines

Water lines

- Powerline

G Hill

Fig. 7 Map of the major roads buffer

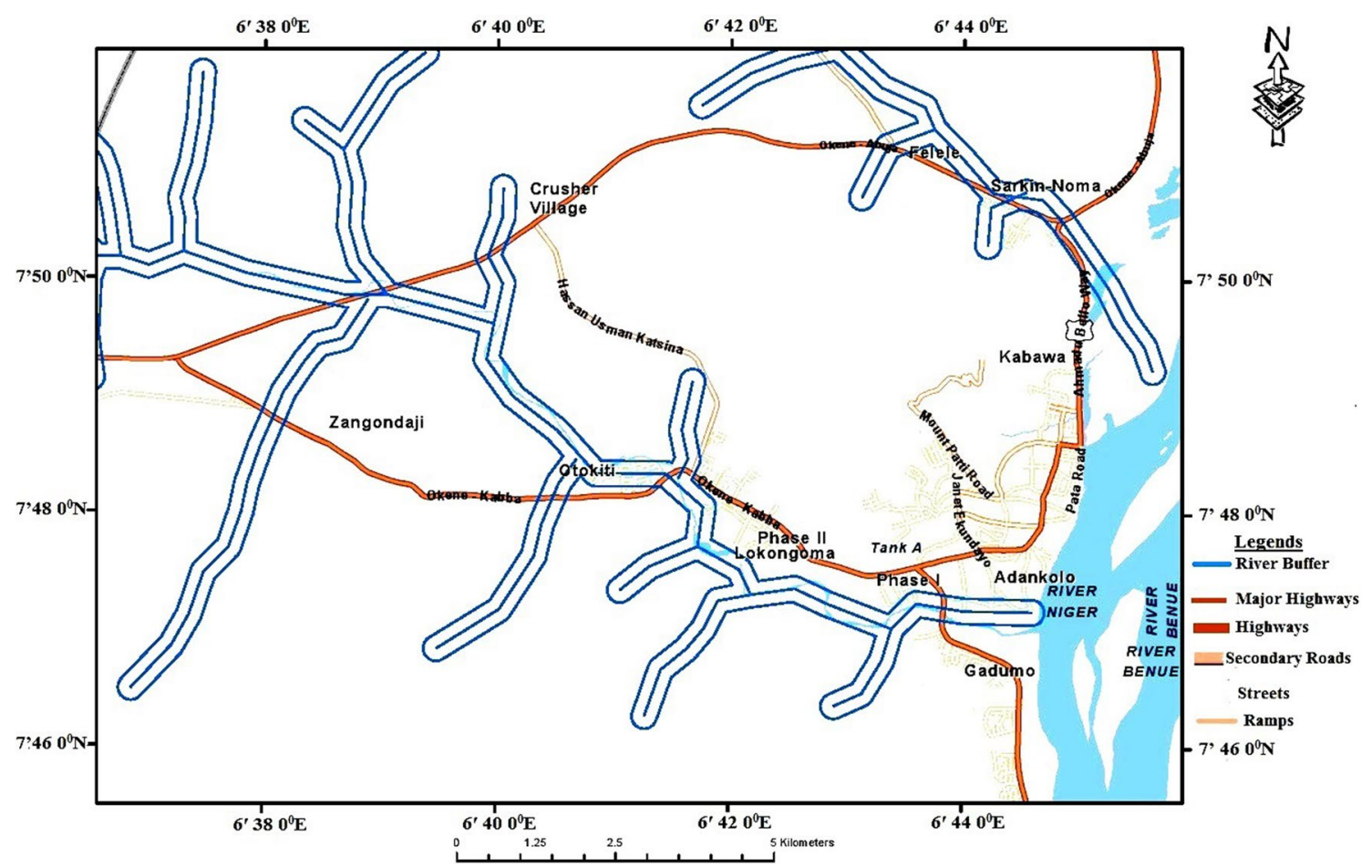

Fig. 8 Map of the water body buffer

SN Applied Sciences 


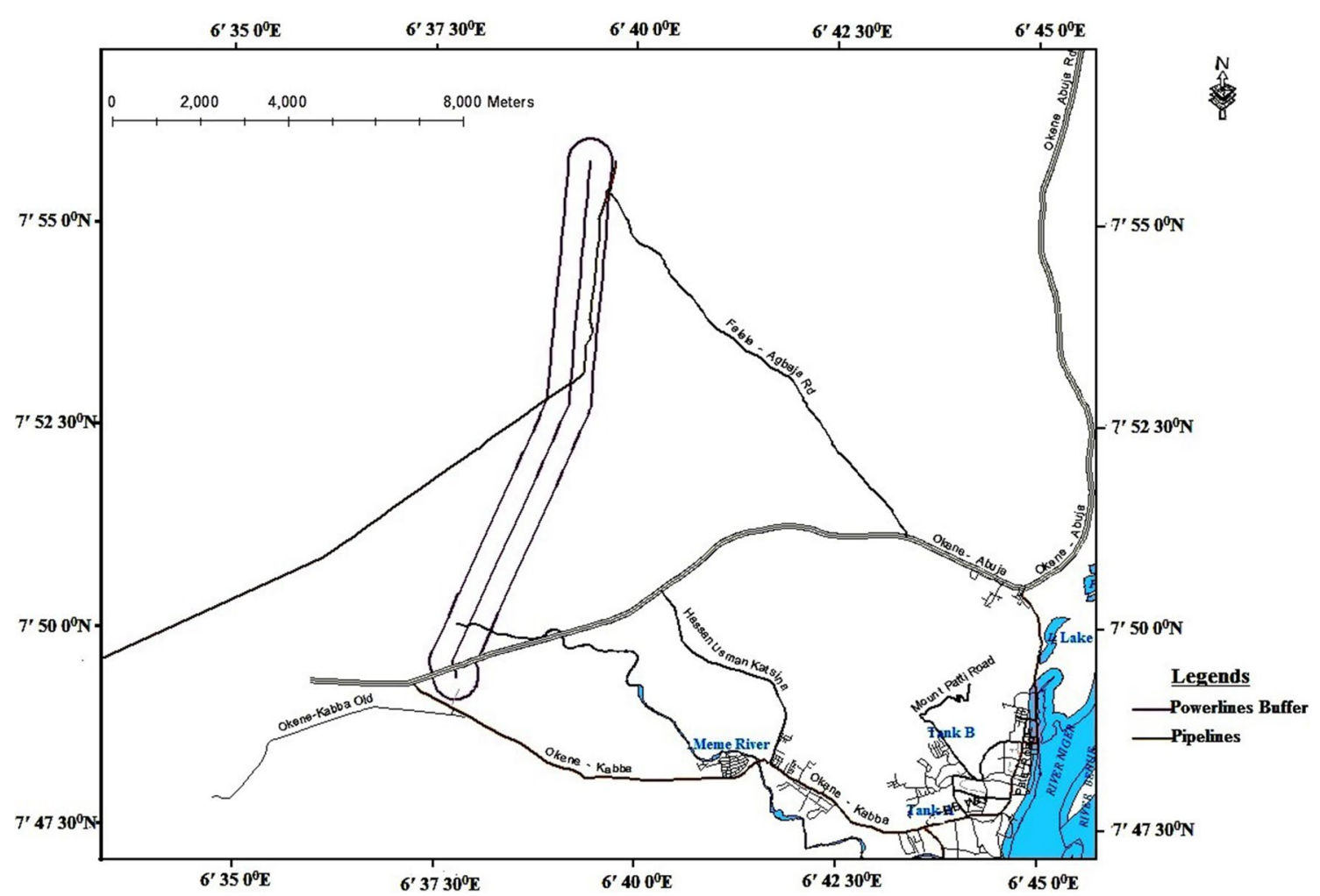

Fig. 9 Powerline buffer map

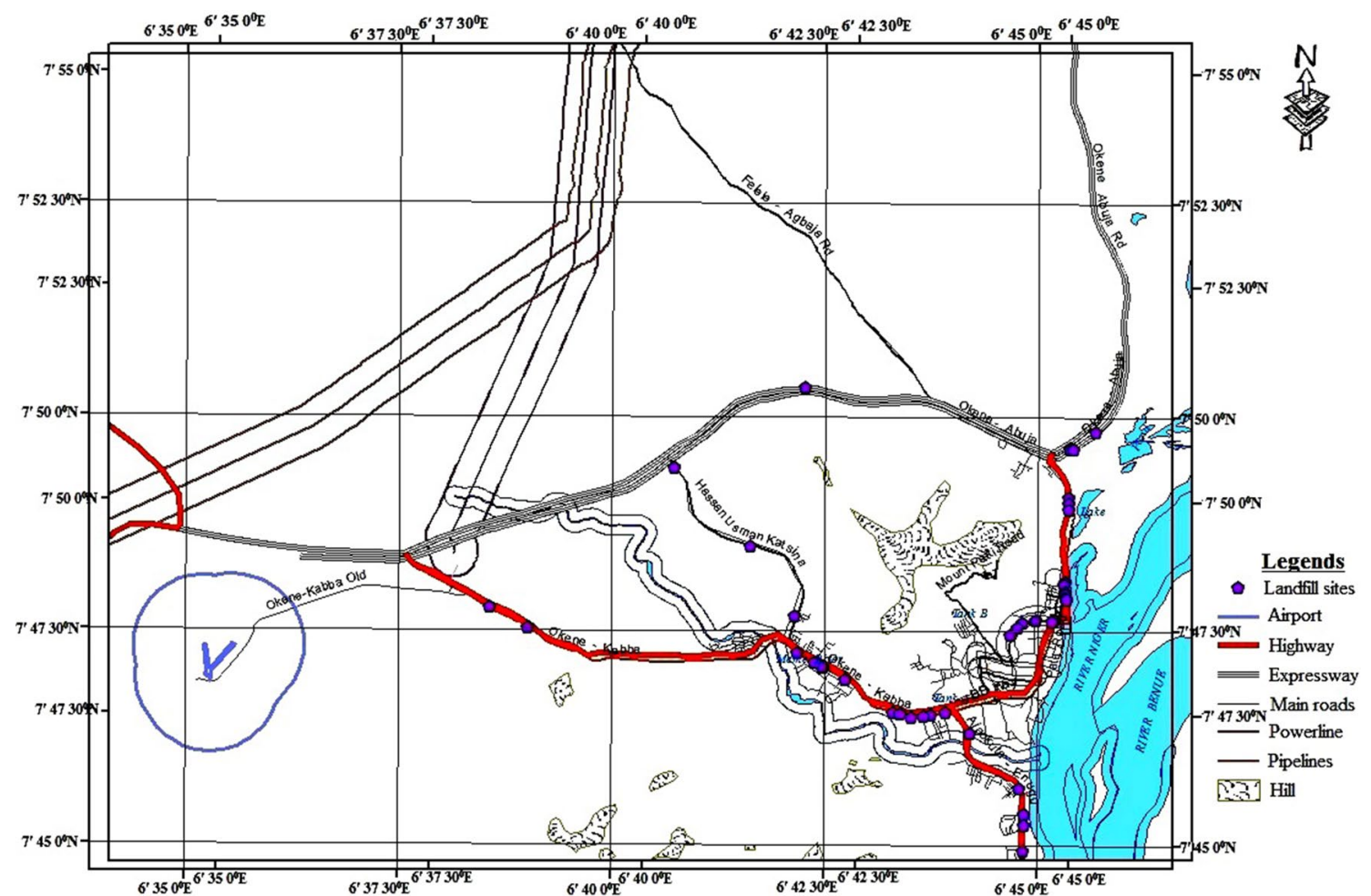

Fig. 10 Map overlay of all the buffered zones 


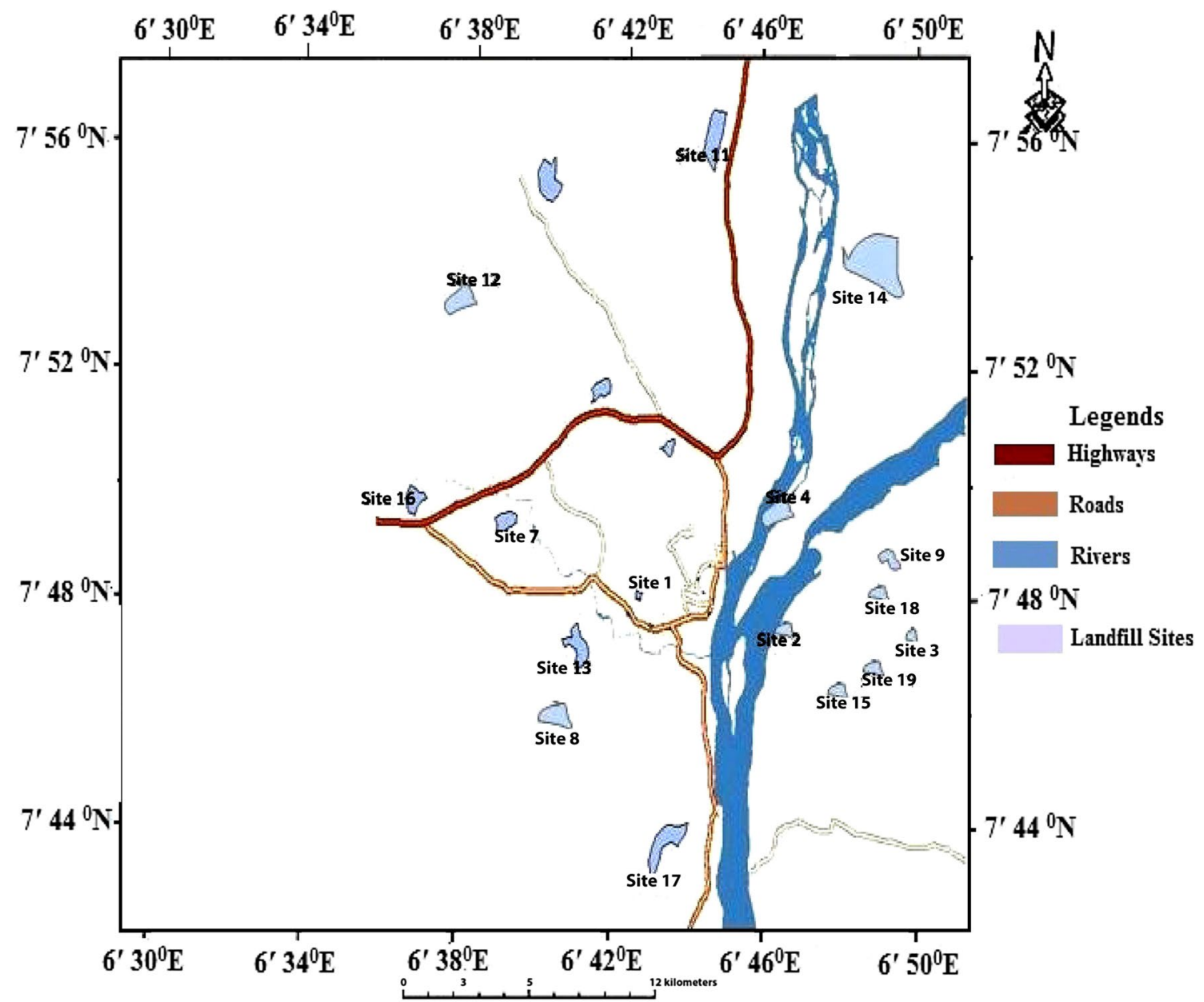

Fig. 11 Map of landfill site identified in the study area

\subsection{Map overlay and collection points for potential landfill sites}

Potential landfill sites were extracted from the combination of the buffered maps of road, water body and powerline (Fig. 10). These locations are where municipal solid waste landfill can be located appropriately based on the various factors considered which include proximity to site, distance to water body, distance to powerline, distance to built-up areas and land use.
The potential landfill sites were further reduced based on geographical locations. Therefore, the boundary sites were not considered for the purpose of selecting the best landfill among various alternatives. Nineteen candidate sites (Fig. 11) were subsequently identified from these potential landfill sites. The characteristic features of these candidate sites and their locations obtained from the GIS analysis are presented in Table 2. The suitable zones are zones considered for landfill site and they are areas with asterisk, while the unsuitable zones are zones not considered for landfill site. The 19 landfill sites 
Table 2 Characteristic features of candidate landfill site and their location

\begin{tabular}{|c|c|c|c|c|c|c|}
\hline $\begin{array}{l}\text { Candidate } \\
\text { landfill site }\end{array}$ & Landfill area $\left(\mathrm{km}^{2}\right)$ & $\begin{array}{l}\text { Proximity to } \\
\text { major road }(\mathrm{m})\end{array}$ & $\begin{array}{l}\text { Proximity to } \\
\text { water body }(\mathrm{m})\end{array}$ & $\begin{array}{l}\text { Proximity to } \\
\text { powerline }(\mathrm{m})\end{array}$ & $\begin{array}{l}\text { Proximity to built- } \\
\text { up area }(\mathrm{m})\end{array}$ & Location \\
\hline 1 & 0.0187 & 201.61 & 260.20 & 1134.02 & 230.14 & Patti \\
\hline 2 & 0.8421 & 556.42 & 2968.49 & 4008.55 & 308.96 & Assembly quarter \\
\hline 3 & 0.5079 & 1011.90 & 608.23 & 7010.49 & 215.22 & 200 Housing units \\
\hline *4 & 5.6230 & 460.31 & 632.32 & 2035.94 & 208.20 & Kogi Poly \\
\hline *5 & 3.2086 & 249.24 & 768.56 & 3001.53 & 260.81 & Elete \\
\hline 6 & 0.9019 & 1346.01 & 1864.34 & 1970.30 & 270.80 & Felele \\
\hline$* 7$ & 8.1348 & 1238.10 & 508.68 & 2010.39 & 216.10 & Barrack area \\
\hline *8 & 2.3121 & 518.80 & 523.78 & 4236.86 & 219.20 & Kabba road \\
\hline 9 & 0.2890 & 284.86 & 1980.68 & 6812.34 & 189.01 & Otokiti estate \\
\hline *10 & 1.3620 & 290.80 & 2024.42 & 6012.02 & 250.48 & Zango \\
\hline$* 11$ & 3.4204 & 210.50 & 1408.20 & 1810.80 & 205.61 & Jimgbe \\
\hline *12 & 2.2334 & 2880.51 & 3030.41 & 1101.20 & 230.20 & GidaBassa \\
\hline 13 & 0.6804 & 530.40 & 584.72 & 3030.40 & 220.20 & Commissioner's Quarter \\
\hline *14 & 1.1616 & 244.30 & 580.30 & 3602.48 & 281.62 & Locongoma \\
\hline$* 15$ & 2.8026 & 218.80 & 540.12 & 3514.40 & 218.72 & 500 Housing units \\
\hline *16 & 2.5687 & 2430.75 & 594.04 & 1980.80 & 200.68 & Ganaja village \\
\hline$* 17$ & 1.2838 & 1742.40 & 504.34 & 3480.86 & 216.76 & Phase 1 \\
\hline 18 & 0.0314 & 204.36 & 640.06 & 3208.60 & 250.64 & Adankolo \\
\hline 19 & 0.6432 & 260.90 & 486.20 & 8986.20 & 202.38 & Phase 2 \\
\hline
\end{tabular}

*The suitable zones considered for landfill site

Table 3 Paired comparison matrix for landfill criteria

\begin{tabular}{llllll}
\hline $\begin{array}{l}\text { Landfill } \\
\text { criteria }\end{array}$ & Road & $\begin{array}{l}\text { Water } \\
\text { body }\end{array}$ & Powerline & $\begin{array}{l}\text { Landfill } \\
\text { areas }\end{array}$ & $\begin{array}{l}\text { Built-up } \\
\text { areas }\end{array}$ \\
\hline Road & 1 & 3 & 5 & 7 & 9 \\
$\begin{array}{c}\text { Water } \\
\text { body }\end{array}$ & 0.3333 & 1 & 0.2000 & 4 & 5 \\
$\begin{array}{c}\text { Powerline } \\
\begin{array}{c}\text { Landfill } \\
\text { areas }\end{array}\end{array}$ & 0.2000 & 5 & 1 & 0.1111 & 7 \\
$\begin{array}{c}\text { Built-up } \\
\text { areas }\end{array}$ & 0.1111 & 0.3333 & 0.2500 & 0.1666 & 1 \\
\hline
\end{tabular}

were subsequently reduced to eleven landfill sites based on geographical location and landfill area of candidate sites. Areas less than $1 \mathrm{~km}^{2}$ (which include sites 1, 2, 3, $6,9,13,18$ and 19) were not considered further for AHP analysis as they will not last up to 20 years. The preliminary factors which are proximity/nearness to the road, distance to water body, distance to powerline, distance to built-up areas and land use were used to consider the adequacy of a site.
Table 4 Normalized matrix for landfill criteria

\begin{tabular}{llllll}
\hline Landfill criteria & Road & Water body & Powerline & Landfill areas & Built-up areas \\
\hline Road & 0.5595 & 0.3147 & 0.7557 & 0.5701 & 0.3214 \\
Water body & 0.1864 & 0.1049 & 0.0302 & 0.3258 & 0.1786 \\
Powerline & 0.1119 & 0.5245 & 0.1511 & 0.0009 & 0.2500 \\
Landfill areas & 0.0798 & 0.0209 & 0.0252 & 0.0814 & 0.2143 \\
Built-up areas & 0.0622 & 0.0349 & 0.0378 & 0.0136 & 0.0357 \\
\hline
\end{tabular}


Table 5 Paired comparison matrix for landfill criteria (re-evaluated)
Table 6 Normalized matrix for landfill criteria (re-evaluated)

\begin{tabular}{lllllc}
\hline Landfill criteria & Road & Water body & Powerline & Landfill areas & Built-up areas \\
\hline Road & 1.0000 & 3.0526 & 2.4280 & 5.9822 & 13.7038 \\
Water body & 0.3275 & 1.0000 & 0.7953 & 1.9596 & 4.4891 \\
Powerline & 0.4118 & 1.2572 & 1.0000 & 2.4638 & 5.6440 \\
Landfill areas & 0.1671 & 0.5103 & 0.4058 & 1.0000 & 2.2907 \\
Built-up areas & 0.0729 & 0.2227 & 0.1771 & 0.4365 & 1.0000 \\
\hline
\end{tabular}

\begin{tabular}{lllllll}
\hline Landfill criteria & Road & Water body & Powerline & Landfill areas & Built-up areas & Priority vector \\
\hline Road & 0.5051 & 0.5051 & 0.5051 & 0.5051 & 0.5051 & 0.5051 \\
Water body & 0.1654 & 0.1654 & 0.1654 & 0.1654 & 0.1654 & 0.1654 \\
Powerline & 0.2080 & 0.2080 & 0.2080 & 0.2080 & 0.2080 & 0.2080 \\
Landfill areas & 0.0844 & 0.0844 & 0.0844 & 0.0844 & 0.0844 & 0.0844 \\
Built-up areas & 0.0368 & 0.0368 & 0.0368 & 0.0368 & 0.0368 & 0.0368 \\
\hline
\end{tabular}

Table 7 Grading of characteristic features of landfill site

\begin{tabular}{llll}
\hline Characteristic feature & Scale & Characteristic feature & Scale \\
\hline Landfill area $\left(\mathrm{km}^{2}\right)$ & & Proximity of water body $(\mathrm{m})$ & \\
$1.0-2.0$ & 3 & $500-510$ & 3 \\
$2.1-3.0$ & 5 & $511-530$ & 5 \\
$3.1-4.0$ & 7 & $531-600$ & 7 \\
$>4.0$ & 9 & $>600$ & 9 \\
Proximity to major road $(\mathrm{m})$ & & Proximity to built-up area $(\mathrm{m})$ & \\
$200-215$ & 9 & $200-210$ & 3 \\
$216-250$ & 7 & $211-217$ & 5 \\
$251-510$ & 5 & $218-220$ & 7 \\
$511-1000$ & 3 & $>221$ & 9 \\
$>1000$ & 2 & & 9 \\
Proximity to pipeline $(\mathrm{m})$ & & & \\
$800-2000$ & 3 & & \\
$2001-3500$ & 5 & & \\
$3501-5000$ & 7 & & \\
\hline
\end{tabular}

\subsection{Analytical hierarchy process (AHP) model}

Comparison matrix developed using Saaty scale in Table 3 was used to get the normalized matrix for landfill criteria in Table 4 in order to produce the local and the global priority which will determine the best suitable site. Consistency check of judgment made in the development of the comparison matrix was done, and the maximum eigenvalue $\left(\lambda_{\max }\right)$, C.I, R.I and C.R were determined using Eqs. $1-5$ to get $5.9159,0.2289,1.1880$ and 0.1926 , respectively. Following the rule of consistency check, the judgment is re-evaluated, since the consistency ratio $(C . R=0.1926)$ is greater than 0.1 to ensure better decision-making and ranking of alternatives. The new paired comparison matrix was developed by pairing the vector priorities of the criteria obtained in Table 4 to 
Table 8 Grading of candidate landfill site with characteristic features

\begin{tabular}{llllll}
\hline Candidate & Landfill & Major & Water & Power- & Built-up \\
landfill site & area $\left(\mathrm{km}^{2}\right)$ & $\begin{array}{l}\text { road }(\mathrm{m}) \\
\text { body } \\
(\mathrm{m})\end{array}$ & $\begin{array}{l}\text { line }(\mathrm{m}) \\
\text { area }(\mathrm{m})\end{array}$
\end{tabular}

\begin{tabular}{cccccc}
\hline $\begin{array}{c}\text { Proximity to } \\
4\end{array}$ & 9 & 5 & 7 & 5 & 3 \\
5 & 7 & 7 & 7 & 5 & 9 \\
7 & 9 & 2 & 7 & 5 & 5 \\
8 & 5 & 3 & 7 & 5 & 7 \\
10 & 3 & 5 & 9 & 9 & 9 \\
11 & 7 & 9 & 5 & 3 & 3 \\
12 & 5 & 9 & 3 & 3 & 9 \\
14 & 3 & 7 & 5 & 7 & 9 \\
15 & 5 & 7 & 3 & 7 & 7 \\
16 & 5 & 2 & 3 & 3 & 3 \\
17 & 3 & 2 & 5 & 5 & 5 \\
\hline
\end{tabular}

give Table 5. The new normalized matrix is presented in Table 6.

The priority vectors: $0.5051,0.1654,0.2080,0.0844$ and 0.0368 are the multiplication coefficient that will be multiplied by the local priority which will give that global priority that determines the suitability of a landfill site. The maximum eigenvalue $\left(\lambda_{\max }\right), C . I, R . I$ and C.R now becomes $5.001796,0.000449,1.62$ and 0.000277 , respectively, and since the consistency ratio (C.R=0.000277) is less than 0.1 , the judgment is acceptable.

\subsection{Development of scale for candidate landfill Sites}

The characteristic features of candidate landfill site were used to determine appropriate scale using Saaty scale developed in 1980 (Table 7) for judgment such that candidate landfill site closer to the road is of extreme importance and vice versa. The combined scale of candidate landfill sites and the corresponding landfill criteria are presented in Table 8. It portrays the candidate landfill site that is above $1 \mathrm{~km}^{2}$ and can serve as landfill site. The grading of candidate landfill site with the feature characteristics in Table 8 is obtained from Tables 2 and 7. Table 8 shows the value to be paired and equally to be normalized with respect to landfill area, road, water body, powerline and built-up area. The paired comparison matrix was developed using the scale. Each candidate landfill site was compared with another using the

Table 9 Normalized and re-evaluated matrix of characteristics features

\begin{tabular}{|c|c|c|c|c|c|c|c|c|c|c|}
\hline \multirow[t]{2}{*}{ Landfill criteria } & \multicolumn{2}{|l|}{ Road } & \multicolumn{2}{|c|}{ Powerline } & \multicolumn{2}{|c|}{ Water body } & \multicolumn{2}{|c|}{ Landfill areas } & \multicolumn{2}{|c|}{ Built-up areas } \\
\hline & NM & $\mathrm{RM}$ & NM & $\mathrm{RM}$ & NM & RM & NM & $\mathrm{RM}$ & NM & RM \\
\hline Maximum eigenvalue $\left(\lambda_{\max }\right)$ & 11.2742 & 11.0935 & 13.0400 & 11.0911 & 11.0340 & 11.0030 & 13.4523 & 11.9918 & 12.7529 & 11.4439 \\
\hline Consistency index (C.I) & 0.2742 & 0.0094 & 0.2050 & 0.0091 & 0.0034 & 0.0030 & 0.2452 & 0.0992 & 0.1753 & 0.0444 \\
\hline Random consistency index (R.I) & 1.62 & 1.62 & 1.62 & 1.62 & 1.62 & 1.62 & 1.62 & 1.62 & 1.62 & 1.62 \\
\hline Consistency ratio (C.R) & 0.1692 & 0.0058 & 0.1250 & 0.0056 & 0.0020 & 0.0018 & 0.1513 & 0.0612 & 0.1082 & 0.0274 \\
\hline
\end{tabular}

NM and RM represent normalized matrix and re-evaluated matrix, respectively

Table 10 Overall rank of candidate sites under various factors considered

\begin{tabular}{lllllll}
\hline Candidate site & $\begin{array}{l}\text { Landfill } \\
\text { area } \\
(0.0844)\end{array}$ & $\begin{array}{l}\text { Water } \\
\text { body } \\
(0.1654)\end{array}$ & Road (0.5051) & $\begin{array}{l}\text { Built- } \\
\text { up area } \\
(0.0368)\end{array}$ & Powerline (0.2080) & Overall rank \\
\hline Proximity to & & & & & \\
4 & 0.0109 & 0.0190 & 0.0484 & 0.0013 & 0.0160 & 0.0956 \\
5 & 0.0085 & 0.0190 & 0.0678 & 0.0039 & 0.0160 & 0.1152 \\
7 & 0.0085 & 0.0190 & 0.0193 & 0.0022 & 0.0160 & 0.0650 \\
8 & 0.0060 & 0.0190 & 0.0290 & 0.0031 & 0.0160 & 0.0731 \\
10 & 0.0036 & 0.0244 & 0.0534 & 0.0064 & 0.0287 & 0.1165 \\
11 & 0.0145 & 0.0136 & 0.0872 & 0.0019 & 0.0287 & 0.1459 \\
12 & 0.0060 & 0.0081 & 0.0200 & 0.0039 & 0.0096 & 0.0476 \\
14 & 0.0100 & 0.0136 & 0.0699 & 0.0039 & 0.0224 & 0.1198 \\
15 & 0.0060 & 0.0081 & 0.0699 & 0.0031 & 0.0224 & 0.1095 \\
16 & 0.0060 & 0.0081 & 0.0200 & 0.0019 & 0.0096 & 0.0456 \\
17 & 0.0036 & 0.0136 & 0.0200 & 0.0048 & 0.0224 & 0.0644 \\
\hline
\end{tabular}


road, powerline, water body, landfill areas and built-up areas criterion selection. The paired comparison matrix and the vector priority (global) of each candidate site were then evaluated and judged. The judgments made were tested for consistencies. The maximum eigenvalue $\left(\lambda_{\max }\right)$, C.I, R.I and C.R were finally determined in order to make a suitable and final decision. Table 9 shows the result for the normalized and re-evaluated matrix of road, powerline, water body, landfill areas and built-up areas. This analysis was performed according to Kapilan and Elangovan [59].

\subsection{Ranking and selection of best candidate site}

The overall rank of the candidate landfill site is evaluated by adding up the priority vector (global) of the landfill under various criteria considered in landfill selection process. The overall rank is presented in Table 10. From Table 10, candidate site 11 has the highest priority vector of 0.1459 and as such considered the best site location among alternatives sites to establish municipal solid waste landfill, while candidate site 16 has the lowest vector priority of 0.0456 and is therefore considered the least suitable site location among alternative sites considered.

\section{Conclusion}

GIS and AHP have been combined to select the wellsuited landfill location in Lokoja, Nigeria. The landfill site selection criteria taken into consideration include proximity to major road, built-up areas, land use, powerline and water bodies. GIS was employed to digitize all the spatial features related to suitably siting landfill areas. A total of 19 candidate landfill sites were identified via the GIS analysis out of which 11 candidate sites were given high priority because their land areas were above $1 \mathrm{~km}^{2}$ and eight candidate sites were eliminated because their land areas were less than $1 \mathrm{~km}^{2}$. AHP model was developed from the GIS result as MCD tool to evaluate these candidate sites so as to choose the most apposite landfill site. The AHP model rated candidate site 11 along Jimg be road as the highly preferable site to locate a landfill in Lokoja which has an approximate area of $3.4204 \mathrm{~km}^{2}$; the distance from the minor road, the nearest water body, powerline and built-up areas to the location is the site which is $210.50 \mathrm{~m}, 1408.20 \mathrm{~m}, 1810.80 \mathrm{~m}$ and $205.61 \mathrm{~m}$, respectively.

The application of GIS-AHP has helped solved timeconsuming challenges which are often associated with selection of landfill site. Environmental planners can easily apply them to spatially buffer unsuitable locations for landfills, identify criteria priorities, and select the most suitable site under each criterion. It can be a measure for siting municipal solid waste landfill in developing areas which minimizes social, economic and environmental impacts which results from municipal solid waste management.

Acknowledgements The authors appreciate the technical support provided by the Centre for Space Research and Applications, Federal University of Technology, Akure, Nigeria. This research received no specific grant from any funding agency in the public, commercial or not-for-profit sectors.

\section{Compliance with ethical standards}

Conflict of interest The authors declare that they have no conflict of interest.

\section{References}

1. Adewumi JR, Ajibade FO, Lasisi KH, Oguntuase AM (2017a) Characterization of Municipal Solid Waste generated in Akure Metropolis. In: Proceedings of the 2017 annual conference of the school of engineering and engineering technology (SEET), The Federal University of Technology, Akure, Nigeria, 11-13 July, pp 584-595

2. Chabuk AJ, Al-Ansari N, Hussain HM, Knutsson S, Pusch R (2016) Landfill siting using GIS and AHP (Analytical Hierarchy Process): a case study Al-Qasim Qadhaa, Babylon, Iraq

3. Alavi MMR, Mokhtarani N, Mokhtarani B (2009) Municipal solid waste management in Rasht City, Iran. Waste Manage 29:485-489

4. Akinbile CO, Ajibade FO, Ofuafo O (2016) Soil quality analysis for dumpsite environment in a university community in Nigeria. FUTA J Eng Eng Technol 10(2):68-73

5. Ojuri OO, Ayodele FO, Oluwatuyi OE (2018) Risk assessment and rehabilitation potential of a millennium city dumpsite in Sub-Saharan Africa. Waste Manag 76:621-628. https://doi. org/10.1016/j.wasman.2018.03.002

6. Zhong S, Gao H, Zhang L, Su H, Zhang C (2017) Spatial distribution and pollution evaluation of heavy metals in soils surrounding a typical municipal solid waste incineration plant in Hang-Jia-Hu plain. Int J Environ Waste Manag 19:74-86. https ://doi.org/10.1504/IJEWM.2017.083563

7. Ali SM, Pervaiz A, Afzal B, Hamid N, Yasmin A (2014) Open dumping of municipal solid waste and its hazardous impacts on soil and vegetation diversity at waste dumping sites of Islamabad city. J King Saud Univ Sci 26:59-65. https://doi.org/10.1016/j. jksus.2013.08.003

8. Yukalang N, Clarke B, Ross K (2017) Barriers to effective municipal solid waste management in a rapidly urbanizing area in Thailand. Int J Environ Res Public Health. https://doi.org/10.3390/ ijerph14091013

9. Yan W, Lou C, Cheng Q, Zhao P, Zhang X (2017) In situ measurement of alkali metals in an MSW incinerator using a spontaneous emission spectrum. Appl Sci 7:263. https://doi.org/10.3390/ app7030263

10. Akinbile CO, Erazua AE, Babalola TE, Ajibade FO (2016) Environmental implications of animal wastes pollution on agricultural 
soil and water quality. Soil Water Res 11(3):172-180. https://doi. org/10.17221/29/2015-SWR

11. Adewumi JR, Ajibade FO (2015) The pollution effect of indiscriminate disposal of wastewater on soil in semi-urban area. J Appl Sci Environ Manag 19(3):412-419. https://doi.org/10.4314/ jasem/v19i3.10

12. Abdunmi T (2012) Landfill gas utilization for energy generation: a case study of Gbagede disposal site, Nigeria. Unpublished M.Eng. Thesis, Department of Agricultural and Bio-systems Engineering, University of Ilorin, Nigeria

13. Abur BT, Oguche EE, Duvina GA (2014) Characteristics of municipal solid waste in the federal capita Territory Abuja, Nigeria. Global J Sci Front Res (H) Environ Earth Sci 14:1-5

14. Rushbrook P, Pugh M (1999) Solid waste landfills in middle- and lower-income countries. The World Bank, Washington, DC

15. Tchobanoglous G, Theisen H, Vigil SA (1993) Integrated solid waste management, engineering principles and management issues, 2nd edn. McGraw-Hill, New York

16. Kontos TD, Komilis DP, Halvadakis CP (2005) Siting MSW landfills with a spatial multiple criteria analysis methodology. Waste Manage 25:818-832

17. Alavi N, Goudarzi G, Babael AA, Jaafarzadeh N, Hossien-Zadeh M (2013) Municipal solid waste landfill site selection with geographic information systems and analytical hierarchy process: a case study in Mahshahr County, Iran. Waste Manage Res 31:98-105

18. Sumathi VR, Natesan U, Sharkar C (2008) GIS-based approach for optimized siting of municipal solid waste landfill. Waste Manage 28:2146-2160

19. Siddiqui M, Everett J, Vieux B (1996) Landfill siting using geographic information system: a demonstration. J Environ Eng 122:515-523

20. Lukasheh AF, Droste RL, Warith MA (2001) Review of expert system (ES), geographical information system (GIS), decision support system (DSS) and their application in landfill design and management. J Waste Manage Res 19:177-185

21. Kontos TD, Komilis DP, Halvadakis CP (2003) Siting MSW landfills in Lesvos Island with a GIS-based methodology. JWaste Manage Res 21:262-277

22. Elahi A, Samadyar H (2014) Municipal solid waste landfill site selection using analytic hierarchy process method for Tafresh Town. Middle East J Sci Res 22:1294-1307

23. Gbanie SP, Tengbe PB, Momoh JS, Medo J, Kabba VTS (2013) Modelling landfill location using geographic information systems (GIS) and multi-criteria decision analysis (MCDA): case study Bo, southern Sierra Leone. Appl Geogr 36:3-12

24. Ajibade FO, Olajire OO, Ajibade TF, Nwogwu NA, Lasisi KH, Alo AB, Owolabi TA, Adewumi JR (2019). Combining multicriteria decision analysis with GIS for suitably siting landfills in a Nigerian State. Environ Sustain Indic (manuscript accepted)

25. Chabuk A, Al-Ansari N, Hussain HM, Knutsson S, Pusch R, Laue $J$ (2017) Combining GIS applications and method of multi-criteria decision-making (AHP) for landfill siting in Al-Hashimiyah Qadhaa, Babylon, Iraq. Sustainability 9:19-32

26. Moeinaddini M, Khorasani N, Danehkar A, Darvishsefat AA, Zienalyan M (2010) Siting MSW landfill using weighted linear combination and analytical hierarchy process (AHP) methodology in GIS environment (case study: karaj). Waste Manage 30:912-920

27. Salman MA, Gholamalifard M (2016) Siting MSW landfills with a weighted linear combination methodology in a GIS environment. Int J Environ Sci Technol 3:435-445

28. Bottero M, Comino E, Riggio V (2011) Application of the analytic hierarchy process and the analytic network process for the assessment of different waste water treatment systems. Environ Model Softw 26:1211-1224
29. Pandey PC, Sharma LK, Nathawat MS (2011) Geospatial strategy for sustainable management of municipal solid waste for growing urban environment. Environ Monitor Assess 184:2419-2431

30. Isalou AA, Zamani V, Shahmoradi B, Alizadeh H (2013) Landfill site selection using integrated fuzzy logic and analytic network process (F-ANP). Environ Earth Sci 68:1745-1755

31. Makropoulos CK, Butler D (2006) Spatial ordered weighted averaging: incorporating spatially variable attitude towards risk in spatial multi-criteria decision-making. J Environ Model Softw 21:69-84

32. Wang G, Qin L, Li G, Chen L (2009) Landfill site selection using spatial information technologies and AHP: a case study in Beijing, China. J Environ Manage 90:2414-2421

33. Sener B, Süzen M, Doyuran V (2006) Landfill site selection by using geographic information systems. Environ Geol 49:376-388

34. National Population Commission (2007) Official Gazette on the National and State Provisional Totals: 2006 Census. Federal Government Printer, Lagos, Nigeria, No. 24

35. Ajadi BS, Tunde AM (2010) Spatial variation in solid waste management in Ilorin Metropolis, Nigeria. J Hum Ecol 32:101-108

36. Stojkovic S, Durdic S, Andelkovic G (2015) Application of multi-criteria analysis and GIS in ecotourism development (case study: Serbian Danube region). Glasnik Srpskog Geografskog Društva 95:51-66

37. Serbu R, Marza B, Borza SA (2016) Spatial analytic hierarchy process for identification of water pollution with GIS software in an eco-economy environment. Sustainability 8:1208-1217

38. Saaty TL (1980) The analytic hierarchy process. McGraw-Hill International, New York, p 287

39. Yousefi H, Yousefi-Sahzabi A, Masih M, Ghaleh S, Mirzaaghabeik M (2017) Urban parks prioritization concerning the age-friendly criteria in Sari, Northern Iran. Int J Occup Hyg 8:116-123

40. Lyu HM, Shen JS, Arulrajah A (2018) Assessment of geohazards and preventative countermeasures using AHP incorporated with GIS in Lanzhou, China. Sustainability 10:304-311

41. Ali S, Lee SM, Jang CM (2017) Determination of the most optimal on-shore wind farm site location using a GIS-MCDM methodology: evaluating the case of South Korea. Energies 10:2072-2089

42. Kontos TD, Halvadakis CP (2002) Development of a Geographic Information System (GIS) for land evaluation for landfill siting: the case of Lemnos Island. In: 7th national conference of Hellenic cartographic society (expanded abstract), Mytilene, Lesvos, pp 98-107

43. Mandylas $\mathrm{CH}$, Balis $\mathrm{M}$, Kontos $\mathrm{TD}$, Akriotis $\mathrm{D}$, Halvadakis $\mathrm{CP}$ (1998) Investigation and evaluation of sites for the construction of a central sanitary landfill in Lesvos. Technical Report, Part I, University of the Aegean, Department of Environmental Studies, Waste Management Laboratory/Region of the North Aegean, Mytilene, Lesvos, Greece

44. Ballis $\mathrm{M}$, Mandylas $\mathrm{CH}$, Kontos $\mathrm{TH}$, Akriotis $\mathrm{D}$, Halvadakis $\mathrm{CP}$ (1998) Investigation of Suitable Areas for the Construction of Sanitary Landfill in Lemnos. Technical Report, Part I, University of the Aegean, Department of Environmental Studies, Waste Management Laboratory/Region of the North Aegean, Mytilene, Lesvos, Greece (in Greek)

45. Bhushan N, Rai K (2004) Strategic decision making: applying the analytic hierarchy process. Springer, New York, p 172

46. Aremu AS (2010) A GIS-AHP optimization strategy for spatial location of municipal solid waste Bins in Ilorin, Nigeria. Unpublished Ph.D Thesis, Department of Civil Engineering, University of llorin, Nigeria

47. Sivaros L, Samsudin SQ, Yusof AR, Tan CF, Mitan NMM, Amran $Y$ (2014) AHP based decision-making in concept selection of keyless grill locking system. Int J Mech Eng 14(4):72-79 
48. Allen A, Brito G, Caetano P, Costa C, Cummins V, Donelly J, Fernandes C, Koukoulas S, O'Donnell V, Robalo C, Vendas D (2002) Procedure for the location of landfill sites using a GIS model. In: Proceedings of 9th congress of the international association for engineering geology and the environment, Durban, South Africa, pp 2704-2713, 16-20 Sept 2002

49. Khan D, Samadder SR (2015) A simplified multi-criteria evaluation model for landfill site ranking and selection based on AHP and GIS. J Environ Eng Landsc Manag. https://doi. org/10.3846/16486897.2015.1056741

50. Al-Anbari MA, Al-Ansari N, Jasim HK (2014) GIS and multicriteria decision analysis for landfill site selection in AlHashimyah Qadaa. Natl Sci 6:282-304. https://doi.org/10.4236/ ns.2014.65032

51. Karimi H, Amiri S, Huang J, Karimi A (2018) Integrating GIS and multi-criteria decision analysis for landfill site selection, case study: Javanrood County in Iran. Int J Environ Sci Technol. https ://doi.org/10.1007/s13762-018-2151-7

52. Dorhofer G, Siebert H (1998) The search for landfill sitesrequirements and implementation in Lower Saxony, Germany. Environ Geol 35(1):55-65. https://doi.org/10.1007/s002540050 292

53. Manual on Municipal Solid Waste Management (2000) Central Public Health and Environmental Engineering Organisation (CPHEEO), 1st edn, Lecture of the Ministry of Urban Development, Government of India, New Delhi

54. Yousefi H, Javadzadeh Z, Noorollahi Y, Yousefi-Sahzabi A (2017) Landfill site selection using a multi-criteria decision-making method: a case study of the Salafcheghan special economic zone. MDPI Sustain 10:1-16. https://doi.org/10.3390/su100 41107
55. Al-Ansari NA, Pusch R, Knutson S (2013) suggested landfill sites for Hazardous waste in Iraq. J Natl Sci 5:463-477. https://doi. org/10.4236/ns.2013.54060

56. Al-Anbari MA, AL-Ansari N, Jasim HK (2014) GIS and multicriteria decision analysis for Landfill site selection in Al-Hashimiyah Qadaa. Nat Sci 6:282-304. https://doi.org/10.4236/ ns.2014.65032

57. Adewumi JR, Akomolafe JK, Ajibade FO, Fabeku BB (2016) Application of GIS and remote sensing technique to change detection in land use/land cover mapping of Igbokoda, Ondo State, Nigeria. J Appl Sci Proc Eng 3(1):34-54

58. Adewumi JR, Akomolafe JK, Ajibade FO (2017) Development of flood prone area map for Igbokoda township using geospatial technique. J Appl Sci Proc Eng 4(2):158-178

59. Kapilan S, Elangovan K (2018) 2018) Potential landfill site selection for solid waste disposal using GIS and multi-criteria decision analysis (MCDA. J Central South Univ 25(3):570-585. https ://doi.org/10.1007/s11771-018-3762-3

60. Demesouka OE, Vavatsikos AP, Anagnostopoulos KP (2014) GIS-based multicriteria municipal solid waste landfill suitability analysis: a review of the methodologies performed and criteria implemented. Waste Manage Res 32(4):270-296. https://doi. org/10.1177/0734242X14526632

Publisher's Note Springer Nature remains neutral with regard to jurisdictional claims in published maps and institutional affiliations. 